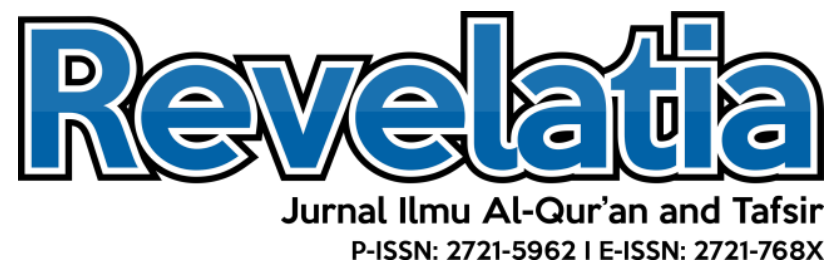

\title{
PEMBACAAN SURAH AL-IKHLASH DALAM TRADISI SHAMADIYAH DI KAMPUNG KREPEK BANGKES KADUR PAMEKASAN
}

\author{
Ummi Maqhfiroh \\ Ilmu al-Qur'an dan Tafsir/Fakultas Ushuluddin dan Dakwah, \\ Email: ummimaqhfiroh84@gmail.com
}

\begin{abstract}
Abstrack:
One of living tradition in Bangkes, Kadur, Pamekasan, is Shamadiyah forum where members read Surah al-Ikhlash. This research aims to observe the practice using qualitative method with phenomenological approach. It uses observation, interviews and documentation as data compilation technique while phenomenological approach. it uses observavation, interviews and documentation as data compilation technique while the analysis is throung descriptive-explanatory. Checking the data validity using extended participation, persistent observations and triangulation, it reveals two results: (1) Shamadiyah is a forum after seven to forty days of anyones's death. Fellows of the forum read Surah al-Ikhlash 100,000 times in a certain period of time using tools such as stationery or the likes to be sent later to the tomb. (2) The recitation implies a wish that it can atone for the deceased's sins as fida'an min al-nar. The community believes that reading Surah al-Ikhlash in that condition can send blessings to the deceased so that it can atone the grave's torture and his/her sins.
\end{abstract}

\section{Abstrak:}

Salah satu tradisi yang hidup di daerah Bangkes, Kadur, Pamekasan adalah forum Shamadiyah yang para anggotanya membaca Surat al-Ikhlash. Penelitian ini bertujuan untuk mengamati praktik, menggunakan metode kualitatif dengan pendekatan fenomenologi. Teknik pengumpulan datanya menggunakan observasi, wawancara dan dokumentasi. Sedangkan, analisisnya melalui deskriptif-eksplanatori. Pengecekan keabsahan data dengan partisipasi diperpanjang observasi gigih dan triangulasi. Hasil penelitian ini ialah: (1) Shamadiyah adalah forum setelah tujuh sampai empat pulu hari kematian siapapun. Para peserta forum membaca Surat al-Ikhlash 100.000 kali dalam kurun waktu tertentu dengan menggunakan alat-alat seperti alat tulis atau sejenisnya untuk kemudian dikirim ke makam. (2) Makna bacaan menyiratkan keinginan agar dapat menebus dosa-dosa almarhum atau almarhummah sebagai fida'an min al-nar. Masyarakat menyakini bahwa membaca Surat al-Ikhlash dalam kondisi tersebut dapat mengirimkan berkah bagi almarhum atau almarhumah sehingga dapat menebus siksaan kubur dan dosa-dosanya.

Kata Kunci: Al-Ikhlash; Shamadiyah; Al-Qur'an 


\section{PENDAHULUAN}

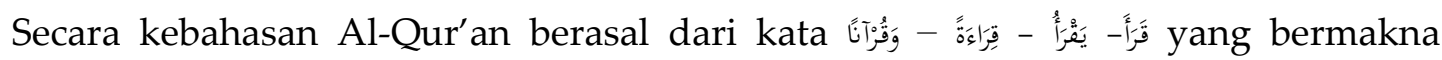

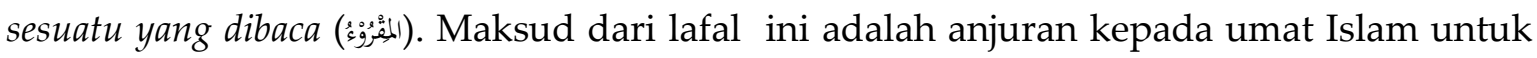
membacanya. Al-Qur'an juga merupakan bentuk mashdar (القِرَاءًَ ) yang berarti menghimpun dan mengumpulkan seolah-olah Al-Qur'an menghimpun huruf, kata dan kalimat dengan tertib sehingga tersusun rapi dan benar. Al-Qur'an harus dibaca dengan benar sesuai dengan makhraj dan sifat-sifat hurufnya serta dipahami, dihayati, diresapi makna-makna yang terkandung didalamnya dan mengamalkannya dalam kehidupan sehari-hari. AlQur'an merupakan firman Allah Swt. dan disampaikan kepada nabi Muhammad Saw., kemudian disampaikan kepada umat Islam dari generasi ke generasi tanpa ada perubahan. ${ }^{1}$

Istilah living quran dapat dimaknai dengan teks Al-Qur'an yang hidup dalam masyarakat Islam. Pada hakikatnya living quran berawal dari fenomena quran in every day life yaitu arti dan fungsi Al-Qur'an yang dipahami dan dialami masyarakat, serta menggunakan Al-Qur'an dalam kehidupan diluar kondisi tekstualnya. Fungsi Al-Qur'an seperti ini muncul dikarenakan adanya praktik pemaknaan Al-Qur'an yang tidak mengacu atas pemahaman terhadap pesan pada tekstualnya, tetapi berlandaskan pada fadhilah (keutamaan) dari suatu unit-unit tertentu teks Al-Qur'an dalam kehidupan keseharian umat. ${ }^{2}$ Al-Qur'an dalam Kamus Besar Bahasa Indonesia (KBBI) merupakan kitab suci umat Islam yang berisi firman Allah Swt. yang diturunkan kepada nabi Muhammad Saw. dengan perantara malaikat Jibril untuk dibaca, dipahami dan diamalkan sebagai petunjuk atau pedoman hidup bagi manusia. ${ }^{3}$

Salah satu tujuan diturunkannya Al-Qur'an adalah keselamatan bagi manusia di dunia dan akhirat. Hal ini yang menjadikan alasan diamalkannya Al-Qur'an pada kehidupan sehari-hari dan sebagai pedoman hidup. Al-Qur'an dijadikan pedoman hidup memiliki dampak pada manusia yang masih hidup dan juga pada manusia yang sudah meninggal sebagai amal yang akan dibawa mati. Bagi manusia yang masih hidup, AlQur'an menjadi pedoman pada setiap aspek kehidupannya. Sebagai contoh ketika manusia berada pada bidang tertentu seperti perekonomian, sosial, warisan, nikah dan lain sebagainya. Manusia menjadikan Al-Qur'an sebagai pedoman karena Al-Qur'an sebagai kitab suci umat muslim. Di alam kubur manusia akan menghadapi berbagai persoalan dimulai dari pertanyaan malaikat dan perlakuan apa yang akan diterima bergantung pada amal yang dilakukan semasa hidupnya. Jika manusia semasa hidupnya melakukan amal baik, maka akan menerima perlakuan baik. Tidak seperti manusia yang beramal buruk ketika meninggal akan mendapat siksa kubur. Akibat seperti ini juga berlaku pada kehidupan akhirat nanti.

${ }^{1}$ Anshori, Ulumul Qur'an Kaidah-Kaidah Memahami Firman Tuhan (Jakarta: Raja Grafindo Persada, 2013), 17.

${ }^{2}$ Nuha Ajami, Metodologi Penelitian The Living Qur'an dan Hadits (Institur Agama Negeri Metro: Kota Metro, t.th), 13.

${ }^{3}$ Kamus Besar Bahasa Indonesia Edisi Keempat (Jakarta: Gramedia Purtaka, 2013), 44. 
Kalam Al-Qur'an tidak hanya ditujukan untuk diri sendiri, tetapi dapat ditujukan pada orang lain baik yang masih hidup atau sudah meninggal. Al-Qur'an yang ditujukan pada orang yang masih hidup dapat berupa doa-doa yang baik untuk orang lain, demikian juga untuk orang yang sudah meninggal. Amal seperti ini dapat dilihat dalam tradisi Shamadiyah yang berisi kegiatan membacakan salah satu surah dalam Al-Qur'an yang ditujukan kepada orang yang meninggal. Sehingga salah satu tujuan diturunkannya Al-Qur'an yang berhubungan dengan penelitian ini adalah pembacaan salah satu surah dalam Al-Qur'an yang ditujukan kepada orang yang sudah meninggal.

Salah satu surah dalam Al-Qur'an adalah surah al-Ikhlash yang merupakan surah ke 112. Surah ini mengandung tauhid sebagai dasar utama keimanan dengan berbagai keutamaan. Keutamaan yang paling umum adalah memiliki kandungan sepertiga AlQur'an jika dilafalkan dan dipahami dengan baik dan benar. ${ }^{4}$ Surah al-Ikhlash bukan Surah terpendek dalam Al-Qur'an, selain al-Ikhlash terdapat Surah dengan jumlah ayat yang lebih sedikit seperti al-Kautsar, an-Nashr dan al-Ashr. Surah ini merupakan Surah Makkiyah. Surah ini diturunkan untuk menjawab pertanyaan kaum Musyrikin yang bertanya tentang Allah sebagai Tuhan yang disembah nabi Muhammad Saw., dan mereka menyangka bahwa Allah Swt. serupa dengan berhala-berhala yang mereka sembah. Dari pertanyaan itulah, kemudian turun Surah al-Ikhlash sebagai jawaban. ${ }^{5}$

Terdapat beberapa nama lain dari Surah al-Ikhlash. Salah satu pakar tafsir Fakhruddin ar-Razi menyebut dua puluh nama Surah al-Ikhlash yaitu at-Tafrid ${ }^{6}$ (Pengesaan Allah), at-Tajrid (penafian segala sekutu bagi-Nya), an-Najah ${ }^{8}$ (Keselamatan dunia akhirat), al-Wilayah ${ }^{9}$ (Kedekatan kepada Allah), al-Ma'rifah ${ }^{10}$ (Pengetahuan tentang Allah), al-Jamal ${ }^{11}$ (Keindahan karena Allah Maha Indah), Qasyqasy' ${ }^{12}$ (Penyembuhan dari kemusryikan), al-Muzakkirah ${ }^{13}$ (Pemberi peringatan), ash-Shamad ${ }^{14}$, al-Aman ${ }^{15}$ dan lainnya.

\footnotetext{
${ }^{4}$ Bachtiar Surin, adz-Dzikraa (Bandung: Angkasa Bandung, 1991), hlm. 2736.

5 M. Quraish Shihab, Tafsir al-Misbah; Pesan, Kesan dan Keserasian al-Qur'an (Jakarta:Lentera Hati, 2002, hlm. 711.

${ }^{6}$ Surat at-Tafrid yaitu keseluruhan ayat dalam surah ini menjelaskan bahwa Allah merupakan Tuhan yang Esa dan Tunggal. Tidak beranak dan tidak pula diperanakkan.

${ }^{7}$ Surat at-Tajrid (mengosongkan) yaitu dalam surat tersebut tidak disebutkan kecuali sifat-sifat salbiyah Allah yang menunjukkan akan keagungannya.

${ }^{8}$ Surah an-Najah (keselamatan), diberi nama an-Najah karena surah ini di dunia akan menyelamatkan seseorang dari tasybih dan kekufuran. Sedangkan di akhirat akan menyelamatkan dari siksa neraka.

${ }^{9}$ Surat al-Wilayah (kedekatan), orang yang membacanya akan menjadi kekasih Allah.

${ }^{10}$ Surat al-Ma'rifah (pengetahuan), karena untuk mengetahui Allah tidak sempurna tanpa mengetahui esensi surah ini.

${ }^{11}$ Surat al-Jamal (keindahan). Rasulullah Saw. Bersabda:"Sesungguhnya Allah itu indah dan menyukai keindahan" (HR. Muslim).

${ }^{12}$ Surat al-Muqasyqisyah (yang menyembuhkan) membebaskan penyakit nifak.

${ }^{13}$ Surah al-Muzakkirah (Pengingat), karena surat tersebut mengingatkan pembacanya untuk memurnikan ketauhidannya. Menbacanya laksana sebuah tanda yang mengingatkan dari kelalaiannya sedangkan ia butuh terhadapnya.

${ }^{14}$ Surat as-Samad (dibutuhkan), karena penyebutan nama ini hanya khusus untuk Allah Swt.

15 Surat al-Aman (keamanan) Rasulullah Saw. Bersabda, Allah Swt. Berfirman:"ketika seorang hamba ia berada dalam bentengku dan siapa pun yang berada dalam bentengku maka ia selamat dari siksaku".
} 
Namun nama yang paling populer adalah al-Ikhlash. Ikhlash berasal dari kata khalish yang berarti suci atau murni. Alasan digunakannya al-Ikhlash adalah mencerminkan kepercayaan seorang yang meyakini keesaan Allah Swt. yang tidak tersentuh dengan kemusyrikan baik nampak atau tidak. ${ }^{16}$

Living quran merupakan gabungan kata living (hidup) dan Quran (kitab suci umat Islam). Al-Qur'an dalam Kamus Besar Bahasa Indonesia (KBBI) merupakan kitab suci umat Islam yang berisi firman Allah Swt. yang diturunkan kepada nabi Muhammad Saw. dengan perantara malaikat Jibril untuk dibaca, dipahami dan diamalkan sebagai petunjuk atau pedoman hidup bagi manusia. ${ }^{17}$ Istilah living quran dapat dimaknai dengan teks AlQur'an yang hidup dalam masyarakat Islam. Pada hakikatnya living quran berawal dari fenomena quran in every day life yaitu arti dan fungsi Al-Qur'an yang dipahami dan dialami masyarakat, serta menggunakan Al-Qur'an dalam kehidupan diluar kondisi tekstualnya. Fungsi Al-Qur'an seperti ini muncul dikarenakan adanya praktik pemaknaan Al-Qur'an yang tidak mengacu atas pemahaman terhadap pesan pada tekstualnya, tetapi berlandaskan pada fadhilah (keutamaan) dari suatu unit-unit tertentu teks Al-Qur'an dalam kehidupan keseharian umat. ${ }^{18}$

Menurut Syamsudin, Al-Qur'an yang hidup dalam masyarakat disebut dengan living quran, yaitu respon masyarakat terhadap teks Al-Qur'an dan penafsiran tertentu. Hal ini dapat ditemukan seperti kegiatan seremonial keagamaan tertentu. Sedangkan menurut M. Yusuf, living quran merupakan respon sosial (realitas) terhadap Al-Qur'an, baik AlQur'an dilihat sebagai ilmu (science) dan sebagai buku petunjuk (huda) yang bernilai sakral. ${ }^{19}$

Kajian living quran juga memberikan kontribusi yang signifikan bagi pengembang wilayah kajian living quran. Jika selama ini tafsir hanya dipahami sebagai teks grafis (kitab atau buku) yang ditulis seseorang, maka makna tafsir sebenarnya diperluas, yaitu tafsir dapat berupa respon atau praktik perilaku suatu masyarakat yang diinspirasi oleh kehadiran Al-Qur'an. Dalam kajian living quran, salah satu tujuannya berupa memahami apa sebenarnya yang mendorong masyarakat untuk mengamalkan Al-Qur'an, makna bagi masyarakat dan mencari relasi antara teks dan praktik..$^{20}$

Sehingga arti sesungguhnya living quran adalah pengamalan ayat-ayat Al-Qur'an yang dibaca dan diamalkan isi kandungannya dikarenakan terdapat fadhilah (keutamaan) tertentu dalam Al-Qur'an. Dari keutamaan inilah masyarakat menjadikannya sebagai pengamalan pada kegiatan tertentu dan berharap mendapat keutamaan tersebut. Sehingga dalam pengamalannya disebut dengan living quran yang berarti Al-Qur'an yang hidup dalam bidang kehidupan tertentu. Disebut demikian, karena terdapat beberapa ayat atau Surah yang diamalkan pada kehidupan masyarakat. Kajian ini

\footnotetext{
16 M. Quraish Shihab, Tafsir al-Misbah; Pesan, Kesan dan Keserasian al-Qur'an, 711.

17 Kamus Besar Bahasa Indonesia Edisi Keempat, (Jakarta: Gramedia Purtaka, 2013), 44.

18 Nuha Ajami, 'Metodologi Penelitian The Living Qur'an dan Hadits', 13.

19 Ibid., 238

${ }^{20}$ Abdul Mustaim, Metode Penelitian al-Quran dan Tafsir (Yogyakarta: Idea Press, 2015), 107
} 
menfokuskan pada bagaimana pemahaman atau pandangan masyarakat tentang Surah tersebut pada tradisi tertentu.

Dalam kajian living quran, ditemukan salah satu seremonial keagamaan yang mengamalkan salah satu Surah dalam Al-Qur'an, yaitu tradisi Shamadiyah yang didalamnya membaca Surah al-Ikhlash dalam jumlah tertentu dan rentang waktu tertentu. Secara kebahasaan Shamadiyah berasal dari salah satu kalimat dalam Surah alIkhlash yaitu أصََمَد (ash-Shamad artinya tempat bergantung) yang merupakan salah satu sifat Allah Swt. sebagai tempat bergantung. Shamadiyah berisi pembacaan doa yang menonjolkan Surah al-Ikhlash. Shamadiyah merupakan tradisi doa bersama yang dikirimkan kepada orang yang meninggal dunia. ${ }^{21}$

\section{METODE PENELITIAN}

Jenis penelitian yang digunakan adalah kualitatif. Tujuan penelitian kualitatif adalah memahami, mencari makna dibalik data untuk menemukan suatu kebenaran. ${ }^{22}$ Sedangkan pendekatan yang digunakan adalah fenomenologi. Fenomenologi merupakan pandangan berfikir yang menekankan pada pengalaman-pengalaman subyektif manusia dan interpretasi-interpretasi dunia. Dalam penelitian ini, peneliti berusaha memahami arti peristiwa dan kaitan-kaitannya terhadap orang-orang yang berada pada situasi tertentu. ${ }^{23}$

Kehadiran peneliti adalah pengumpul data. Instrumen yang digunakan seperti angket, wawancara, observasi dan dokumentasi. Sehingga kehadiran peneliti adalah mutlak, karena peneliti harus berinteraksi dengan lingkungan baik manusia dan nonmanusia yang ada di lokasi penelitian. Dalam kehadirannya, harus jelas apakah kehadiran peneliti di lapangan diketahui atau tidak oleh subyek penelitian. Hal ini berkaitan dengan keterlibatan peneliti dalam penelitian apakah terlibat aktif atau pasif. ${ }^{24}$ Sehingga peneliti berperan aktif di lapangan terutama dalam fenomena yang diteliti dan keberadaannya diketahui oleh partisipan lain. Lokasi penelitian yang akan dituju adalah kampung Krepek Dusun Embung Barat Utara Desa Bangkes Kecamatan Kadur Kabupaten Pamekasan. Dalam kampung Krepek, tradisi dengan nama Shamadiyah masih dilestarikan

Sumber data yang akan didapatkan berasal dari dua sumber data yaitu sumber data primer dan sekunder. Sumber data primer adalah sumber data yang diperoleh dari hasil observasi maupun wawancara atau dokumentasi dengan masyarakat kampung Krepek untuk mendapat informasi tentang pembacaan Surah al-Ikhlash dalam tradisi Shamadiyah. Sedangkan sumber data sekunder merupakan sumber data yang berasal

\footnotetext{
${ }^{21}$ http://www.nu.or.id/post/read/39568/Samadiyah-wujud-kesalehan-anak diakses pada 1 April 2019.

${ }^{22}$ Moh. Kasiram, Metodologi Penelitian Kualitatif-Kuantitatif (Yogyakarta: Sukses Offset, 2008), 177

${ }^{23}$ Andi Prastowo, Metode Penelitian Kualitatif Dalam Perspektif Rancangan Penelitian, hlm. 28

${ }^{24}$ Wahidmurni, 'Pemaparan Metode Penelitian Kualitatif,' UIN Maulana Malik Ibrahim, Malang, Juli 2017, 5
} 
dari arsip-arsip dan dokumentasi, serta dapat berupa buku tafsir, jurnal, artikel atau penelitian serta literatur pendukung lainnya..$^{25}$

Prosedur pengumpulan data yang dilakukan sebagai berikut: ${ }^{26}$

Observasi

Dalam observasi bebas, peneliti memiliki kedudukan sebagai pengamat saja, sebaliknya pada pengamatan terlibat yang juga peneliti ikut serta menjadi anggota dikelompok yang diteliti dan melibatkan dirinya sendiri. Dalam penelitian ini, peneliti hanya sebagai pengamat, dikarenakan tradisi semacam ini ada hanya ketika ada orang meninggal saja.

Wawancara

Dalam penelitian ini, peneliti menggunakan teknik purposif rasional (purposive sampling) dan bola salju/bergulir (snow ball). Teknik purposif rasional digunakan ketika peneliti memiliki informasi awal informan yang lebih mengetahui seluk-beluk fenomena tersebut. Namun, ketika diwawancara maka tidak dapat menutup kemungkinan informasi yang diwawancarai menunjuk orang lain sebagai informan lanjutan dan dianggap lebih mengetahui tentang fenomena tersebut.

Dokumentasi

Dokumentasi digunakan untuk melengkapi data-data yang sudah ada. Dokumentasi dapat berupa buku, arsip, atau literatur lainnya.

Analisis data yang dipilih adalah analisis data deskriptif-eksplanatif. Analisis deskriptif merupakan menganalisis data-data yang telah didapat sebelumnya dan diperoleh dari hasil observasi, wawancara dan dokumentasi. ${ }^{27}$ Deskriptif berasal dari kata deskripsi, secara bahasa berasal dari bahasa Inggris description yang artinya pemaparan atau penggambaran dengan kata-kata secara jelas dan rinci. Sehingga penelitian deskriptif berarti penelitian yang dimaksudkan untuk mengumpulkan informasi mengenai status suatu gejala yang ada, apa adanya pada saat penelitian dilakukan. ${ }^{28}$ Analisis deskriptif digunakan untuk memaparkan atau menggambarkan data-data lapangan yang diperoleh berkenaan dengan pembacaan surah al-Ikhlash pada tradisi Shamadiyah.

Adapun analisis eksplanatif mengungkapkan makna yang terkandung dalam tradisi tertentu. ${ }^{29}$ Dalam penelitian ini, analisis eksplanatif digunakan untuk mengungkap makna dari adanya sebuah tradisi dan pembacaan surah al-Ikhlash pada tradisi Shamadiyah. berikut: ${ }^{30}$

Teknik yang digunakan untuk mengecek keabsahan data temuan sebagai

\footnotetext{
${ }^{25}$ Ibrizatul Ulya, "Pembacaan 124.000 Kali Surah Al-Ikhlash Dalam Ritual Kematian Di Jawa”, 18

${ }^{26}$ Ibid., 18-19

27 Ibid., 20

${ }^{28}$ Nasaruddin Baidan dkk, Metodologi Khusus Penelitian Tafsir (Yogyakarta: Pustaka Pelajar, 2016), 70

${ }^{29}$ Ibrizatul Ulya, "Pembacaan 124.000 Kali Surah Al-Ikhlash Dalam Ritual Kematian Di Jawa, hlm. 20

${ }^{30}$ Lexy J. Moleong, Metodologo Penelitian Kualitatif (Bandung: Remaja Rodaskarya, 2017), hlm. 322-326
} 
Perpanjangan keikutsertaan

Perpanjangan keikutsertaan berarti penulis tinggal di lapangan penelitian sampai kejenuhan pengumpulan data tercapai. Perpanjangan keikutsertaan penelliti akan memungkinkan derajat data yang dikumpulkan. Hal tersebut dikarenakan peneliti akan semakin banyak mempelajari 'kebudayaan', dapat menguji ketidak benaran informasi yang diperkenalkan oleh distorsi yang derasal dari diri sendiri maupun dari responden dan membangun kepercayaan dengan subyek penelitian. Hal ini juga menuntut peneliti untuk terjun langsungg ke lokasi dan dalam waktu cukup panjang untuk mendeteksi dan memperhitungkan distorsi yang mungkin dapat mengotori data.

Ketekunan/keajegan pengamatan

Dalam tahap ini berarti mencari cara konsisten interpretasi dengan berbagai cara dalam kaitan dengan proses analisis yang konstan atau tentatif. Pada perpanjangan keikutsertaan adalah memungkinkan peneliti terbuka terhadap pengaruh ganda yaitu faktor-faktor konseptual dan pengaruh bersama pada peneliti dan subyek yang pada akhirnya mempengaruhi fenomena yang diteliti. Sedangkan ketekunan pengamatan bermaksud menemukan ciri-ciri dan unsur-unsur dalam situasi yang sangat relevan dengan persoalan atau isu yang dicari dan kemudian memusatkan diri pada hal-hal tersebut secara rinci. Sehingga perpanjangan keikutsertaan menyediakan lingkup, maka ketekunan pengamatan menyediakan kedalaman.

Triangulasi

Triagulasi merupakan teknik pemeriksaan data yang memanfaatkan data yang lain. Diluar data itu untuk keperluan pengecekan atau pembanding terhadap data. teknik ini paling banyak digunakan ialah melalui pemeriksaan sumber lainnya. Triangulasi pada hakikatnya mengecek kebenaran data atau informasi yang diperoleh peneliti dari berbagai sudut pandang yang berbeda. Triangulasi dapat meningkatkan kedalaman pemahaman peneliti baik mengenai fenomena yang diteliti maupun konteks fenomena itu muncul. ${ }^{31}$

Tahap penelitian yang akan dilakukan adalah sebagai berikut: ${ }^{32}$ Tahap Pra Lapangan

Pada tahap pra lapangan ini terbagi lagi menjadi eman tahap, yakni menyusun rancangan penelitian, memilih lapangan penelitian, memilih dan memanfaatkan informan, menyiapkan perlengkapan penelitian dan tahap pekerjaan lapangan.

Pada tahap pekerjaan lapangan ini terbagi menjadi tiga tahap, yakni memahami latar penelitian dan persiapan diri, memasuki lapangan, berperan serta sambil mencari data dan tahap analisis data.

\footnotetext{
${ }^{31}$ http://repository.uin-malang.ac.id/1133/1triangulasi.pdf diakses pada 26 Januari 2019

${ }^{32}$ Moh. Kasiram, Metodologi Penelitian Kualittif-Kuantitatif, hlm. 281-287
} 
Pada tahap ini peneliti melakukan pengecekan, pengorganisasian, serta memaparkan dengan mendeskripsikan hasil temuannya. Analisis data secara sederhana adalah proses mengatur urutan data, mengorganisasikannya dalam suatu pola, kategori, dan satuan uraian dasar.

Dalam hal ini, tahap analisis data dilakukan dengan mengorganisasikan data, memilah-milahnya menjadi satuan yang dapat dikelola, mencari dan menemukan pola apa yang penting dan apa yang dipelajari, dan memutuskan apa yang dapat diceritakan kepada orang lain. Dengan demikian tahap analisis data ini terdiri dari pengorganisasian data dan kategori data serta menceritakan atau mendeskripsikan data yang diperoleh dalam bentuk laporan tertulis.

\section{HASIL DAN PEMBAHASAN}

Kampung Krepek merupakan salah satu kampung yang terletak dusun Embung Barat Utara desa Bangkes kecamatan Kadur kabupaten Pamekasan. Nama kampung Krepek berawal dari sebuah tempat yang terdapat banyak batu lebar dan besar seperti hamparan. Sehingga tempat itu dinamakan kampung Krepek. Bahkan batu tersebut yang masih tersisa sampai saat ini masih ada dan dianggap keramat, karena pernah terjadi sebuah tragedi seorang laki-laki yang menjadi gila karena berteriak di sekitar batu tersebut. ${ }^{33}$

Kampung Krepek terletak di desa Bangkes kecamatan Kadur kabupaten Pamekasan. Terdapat sejarah yang dipercaya masyarakat asal mula dari desa Bangkes. Sebelum disebut desa Bangkes, datang seorang santri sunan Giri yang bernama Agung Hanafi. Agung datang ke perbukitan di Jalinan yang masyarakat sekarang menyebutnya Bhuju' Agung Hanafi. Kedatangan Agung dikarenakan tanggung jawab untuk menyebarkan agama Islam. Agung mendirikan padepokan (rumah) yang tiangnya terbuat dari pohon Pakes dan atapnya dari daun Siwalan (orang Madura menyebutnya daun Brangbang). Masyarakat menilai Agung sebagai orang yang kurang waras karena bahan padepokannya dari pohon Pakes dan beratap daun Brangbang. Selain itu juga sering mengobati orang sakit dan memiliki keajaiban. Sejak saat itulah Agung menjadi terkenal dan masyarakat menyebutnya dengan istilah Bangkes yang diambil dari kata Brangbang dan Pakes.

Lokasi penelitian yang dipilih adalah kampung Krepek dusun Embung Barat Utara desa Bangkes kecamatan Kadur kabupaten Pamekasan, karena lokasi tersebut melestarikan Shamadiyah. Bagi masyarakat kampung Krepek, Shamadiyah merupakan perkumpulan yang diadakan saat ada orang yang meninggal (kifayah) dan dilakukan pada hari ke tujuh sampai empat puluh hari.

\footnotetext{
${ }^{33}$ Shamad, Tokoh masyarakat, wawancara langsung, (22 Agustus 2019)
} 
Pada dasarnya Shamadiyah membaca ayat-ayat Al-Qur'an yang dilaksanakan saat ada kematian. ${ }^{34}$ Pendefinisian seperti ini sesuai dengan teori bahwa dalam pelaksanaan Shamadiyah menonjolkan pembacaan Surah al-Ikhlash dengan jumlah tertentu. Secara kebahasaan Shamadiyah berasal dari salah satu kalimat dalam Surah alIkhlash yaitu ash-Shamad (أصَّمَد) artinya tempat bergantung yang merupakan salah satu sifat Allah Swt. sebagai tempat bergantung. Shamadiyah berisi pembacaan doa yang menonjolkan Surah al-Ikhlash dan merupakan tradisi doa bersama yang dikirimkan kepada orang yang telah meninggal dunia. ${ }^{35}$

Shamadiyah juga dimaknai sebuah kegiatan yang dilakukan dengan pengharapan penebus dosa orang yang meninggal dari dosa yang paling kecil hingga yang paling besar atau sebagai fidaan min al-nar (penebus dosa dari api neraka). Makna ini sesuai dengan tujuan pelaksanaan Shamadiyah pada tradisi Kenduri Peutron Aneuk di Aceh, yaitu selain sebagai rasa syukur pada Allah Swt. juga sebagai upaya untuk mengirimkan doa pada arwah orang yang lebih dahulu meninggal. ${ }^{36}$ Shamadiyah juga terdapat dalam tradisi Kenduri Jirat yang memiliki tujuan yang sama yaitu mendoakan orang yang meninggal. ${ }^{37}$

Shamadiyah dilakukan pada hari ke tujuh sampai empat puluh hari. Shamadiyah dari segi penamaannya diambil dari salah satu kalimat dalam Surah alIkhlash ash-Shamad (ألصَمَد) artinya bergantung pada Allah Swt. Pernyataan tersebut sesuai dengan beberapa referensi yaitu makna ash-Shamad (ألصَّمَد) yang dijadikan tumpuan dalam segala kebutuhan, karena hanya Dia yang mampu memenuhi kebutuhan makhluk-Nya. Tiada makhluk yang merasa lebih kaya dari-Nya. Pada dasarnya Dia tidak membutuhkan sama sekali mereka. ${ }^{38}$ Ash-Shamad memliki dua makna utama yaitu sesuatu yang tidak berongga dan yang menjadi tumpuan harapan. Bagi ulama ash-Shamad adalah sesuatu yang tidak berongga berarti sesuatu yang sangat padat dan tidak membutuhkan sesuatu untuk dimasukkan ke dalam dirinya, seperti makanan atau minuman, tidak beranak dan diperanakkan sebagaimana yang ditegaskan dalam Surah al-Ikhlash. Makna lain menekankan pada keesaan Allah Swt. yang berarti tidak dapat dibagi-bagi dan Dzat yang tidak tersusun dari unsur apapun. ${ }^{39}$

\footnotetext{
${ }^{34}$ Departemen Pendidikan Dan Kebudayaan, Upacara Tradisional (Upacara Kematian)Daerah Istimewa Aceh (Jakarta: Departemen Pendidikan dan Kebudayaan Proyek Inventarisasi dan Dokumentasi Kebudayaan Daerah, 1984) 22

${ }^{35} \mathrm{http} / / /$ www.nu.or.id/post/read/39568/samadiyah-wujud-kesalehan-anak diakses pada 1 April 2019

${ }^{36}$ Intan Ervina, "Ritual Peutron Aneuk dan Dampaknya Terhadap Kehidupan Masyarakat di Gampong Tokoh Kecamatan Manggeng Kabupaten Aceh Barat Daya", (Skripsi S.KI, Universitas Islam Negeri Ar-Raniry, Aceh, 2017), 27.

${ }^{37}$ Maslita, "Kenduri Jirat di Gampong Ruak Kecamatan Kluet Utara Kabupaten Aceh Selatan (Ritual, Ajaran, Nilai)", hlm. 61.

${ }^{38}$ Wafi Marzuqi Ammar, Tafsir Tematik al-Wafi : Menyelami Kandungan Ayat Sesuai Tema dari Surahsurah dalam Al-Qur'an (Gresik: Waraqah Mitra Media, 2013), 454

${ }^{39}$ M. Quraish Shihab, Tafsir al-Misbah: Pesan,Kesan dan Keserasian al-Qur'an, 720
} 
Salah satu narasumber memaknai Shamadiyah yang memiliki fungsi sama dengan tahlil sehingga disebut dengan tahlil Shamadiyah. Bagi masyarakat kampung Krepek, Shamadiyah dilakukan dengan tujuan mengharap penebus dosa orang yang meninggal (fidaan min al-nar). Pendapat ini sesuai dengan teori bahwa tahlil merupakan perkumpulan orang-orang untuk melakukan doa bersama untuk orang yang meninggal. Secara kebahasan tahlil berasal dari kata hallala-yuhallilu-tahlilan yang berarti membaca kalimat la ilaha illallah. ${ }^{40}$ Tujuan utama dari tahlil untuk orang meninggal adalah berdoa supaya diampuni segala dosa tanpa terkecuali, dihindarkan dari siksa kubur dan neraka, serta dihindarkan dari kengerian hari kiamat dan diberikan tempat terbaik. ${ }^{41}$ Keduanya memiliki tujuan yang sama yaitu pengharapan penebusan dosa orang yang meninggal agar terhindar dari siksa api neraka. Perbedaannya terletak pada jumlah bacaan Surah alIkhlash yang dibaca. Surah al-Ikhlas yang dibaca dalam tradisi Shamadiyah memiliki jumlah tertentu yaitu 100.000, sedangkan dalam tahlil surah al-Ikhlash di baca beberapa kali saja.

Masyarakat kampung Krepek tidak mengetahui bagaimana asal usul Shamadiyah. Shamadiyah sudah ada sejak lama atau turun temurun dari sesepuh. Mereka mengetahui bahwa Shamadiyah berasal dari cerita ulama. Ketika seorang ulama meninggal, ada banyak tamu, tamu tersebut diberi kerikil diminta untuk membaca Surah al-Ikhlash yang dikhususkan kepada yang meninggal sebagai doa.

Tidak ditemukan teori atau kajian ilmiah yang menjelaskan bagaimana asal-usul dari Shamadiyah. Namun, fenomena Shamadiayah sesuai dengan pendekatan yang peneliti gunakan yaitu fenomenologi. Fenomenologi merupakan pandangan berfikir yang menekankan pada pengalaman-pengalaman subyektif manusia dan interpretasiinterpretasi dunia. Dalam penelitian ini, peneliti berusaha memahami arti peristiwa dan kaitan-kaitannya terhadap orang-orang yang berada pada situasi tertentu. ${ }^{42}$ Sehingga fenomenologi membiarkan semua gejala menampakkan dirinya apa adanya dari sebuah pengalaman yang dialami manusia. Menurut Max Weber, pengertian yang dimaksud adalah verstehen (pemahaman mendalami atau indepth). Tujuan fenomenologi adalah menangkap arti pengalaman hidup manusia tentang suatu gejala. Metode fenomenologi hendak mengetahui lebih dalam struktur kesadaran dan pengalaman manusia. ${ }^{43}$

Dari pengalaman masyarakat kampung Krepek, peneliti menyimpulkan bahwa mereka hanya mengikuti dan melestarikan Shamadiyah. Hal yang paling utama mendasari pelestarian suatu kegiatan yang sudah mereka alami dari waktu kewaktu sebelumnya karena berasal dari pengalaman baik dari sesepuh, lingkungan atau diri sendiri. Pengalaman semacam ini juga dipengaruhi oleh berbagai interpretasi dan pemahaman tiap individunya. Ditinjau dari semua narasumber yang menjelaskan tentang

40 Muhammad Solikhin, Ritual Kematian Islam Jawa: PengaruhTradisi Lokal Indonesia Dalam Ritual Kematian Jawa (Yogyakarta: Narasi, 2010), 151

${ }^{41}$ Ibid., 156

${ }^{42}$ Andi Prastowo, Metode Penelitian Kualitatif Dalam Perspektif Rancangan Penelitian, 28

43 J.R. Raco, Metode Penelitian Kualitatif Jenis, Karakteristik, dan Keunggulannya (Jakarta: Grasindo, 2010), 40-41 
keutamaan Shamadiyah, mereka memahami bahwa kegiatan semacam ini tidak hanya dilakukan tanpa dasar. Mereka memiliki dasar dan tujuan sendiri yang berasal dari pemahaman akan urgensinya sebuah Shamadiyah. Urgensi yang paling utama adalah penebusan dosa orang yang meninggal dari siksa api neraka melalui pembacaan Surah Al-Qur'an (al-Ikhlash) dengan jumlah tertentu. Mereka memahami keutamaan Surah alIkhlash dan pentingnya berdoa untuk orang yang meninggal. Pemahaman mereka tentang keutamaan surah al-Ikhlash yang mereka amalkan dengan keyakinan mendapat rahmat dan barokah untuk diri sendiri dan orang lain. Adanya fenomena Shamadiyah, maka Surah al-Ikhlash yang mereka amalkan dalam tradisi Shamadiyah menunjukkan bahwa Al-Qur'an itu hidup di tengah masyarakat. Inilah yang disebut dengan living quran

Mereka menyatakan siapa saja bisa ikut melaksanakan Shamadiyah, bahkan orang dari jauh pun bisa ikut melaksakan untuk menyumbang jumlah Surah al-Ikhlash yang sudah dibacanya melalui media seperti telepon. Orang yang tentu berpartisipasi dalam Shamadiyah adalah keluarga dan tetangga. Namun, tidak lupa tuan rumah untuk memberikan suguhan kepada orang yang berpartisipasi sebagai tanda terima kasih. Peneliti tidak menemukan teori yang membahas tentang ketentuan partisipan dalam Shamadiyah, serta diperkuat dengan observasi yang peneliti lakukan bahwa partisipan Shamadiyah siapa saja boleh ikut bahkan orang yang jauh bisa ikut menyumbang melalui media dan jumlah tersebut dimasukkan dalam catatan.

Pernyataan narasumber dapat dikategorikan sebagai penemuan baru selama peneliti observasi dan mengumpulkan data. Hal ini dikarenakan pada umumnya tidak pernah menemukan bahwa orang yang jauh juga bisa ikut berpartisipasi dalam Shamadiyah melalui media seperti telepon, sedangkan secara kekeluargaan dan tetangga sudah umum dilakukan di daerah lainnya. Serta tidak ditemukannya kajian ilmiah atau teori tentang penemuan tersebut.

Data lapangan yang diperoleh menjelaskan bahwa tuan rumah biasanya melaksanakan Shamadiyah setelah tujuh hari sampai empat puluh hari kematian. Namun pelaksanaan ini tidak ditekankan untuk dilaksanakan bahkan waktu pelaksanaannya tidak harus selepas hari ke tujuh kematian, tapi bisa kapan saja bergantung tuan rumah yang menentukan. Dapat diambil kesimpulan dari paparan di atas bahwa pelaksanaan Shamadiyah dilakukan ketika terdapat orang yang meninggal. Hal ini bergantung pada keluarga orang yang meninggal. Pada umumnya dilaksanakan pada malam ke tujuh hingga malam ke empat puluh kematian. Waktu pelaksanaan Shamadiyah peneliti tidak menemukan kajian ilmiah yang menjelaskan waktu pelaksanaan Shamadiyah.

Data lapangan yang diperoleh melalui wawancara, semua narasumber menyatakan bahwa jumlah Surah al-Ikhlash yang dibaca dalam Shamadiyah adalah 100.000 kali (selaksa atau 'sabu-èbu'). Hal ini sesuai dengan penjelasan tentang fidaan minan nar (penebus dosa dari api neraka) yang telah narasumber nyatakan. Orang yang menghadiri perkumpulan dengan tujuan mendoakan orang yang meninggal membaca Surah al-Ikhlash hingga mencapai 100.000 kali untuk dihadiahkan pada almarhum atau 
almarhumah dalam rentang waktu tertentu. Hal ini sesuai dengan penjelasan sebagai berikut: ${ }^{44}$

Sebagian dari fadlilah surat al-ikhlash, sesungguhnya orang yang membacanya 100.000 kali, dia telah membeli dirinya sendiri dari Allah dan Malaikat akan mengumumkan dari sisi Allah di langit dan di bumi "Ketahuilah! sesungguhnya si fulan adalah hamba yang dimerdekakan oleh Allah, siapa saja yang mempunyai hak yang di tanggung fulan maka mintalah dari Allah". Surat al-Ikhlas itu akan memerdekakannya dari neraka, tetapi dengan syarat tidak mempunyai tanggungan pada orang lain, atau punya tanggungan tapi tidak mampu membanyarnya. (Tafsir As-Shoowi, Juz 4 hal. 498 (Ahmad Shoowi Al-Maliki))

Beberapa informan menyebut jumlah hitungan Surah al-Ikhlas dengan istilah selaksa yang artinya ribuan kali atau 100.000 kali. Hal ini sesuai dengan pengertian selaksa yaitu sangat banyak. Biasanya untuk mengungkapkan sesuatu yang tidak terhingga. ${ }^{45}$ Namun ada beberapa sumber yang menyatakan bahwa selaksa berarti sepuluh ribu (10.000) bukan seratus ribu (100.000). ${ }^{46}$ Sehingga jika merujuk pada istilah jumlah yang bermakna jumlah yang tidak terhingga atau sangat banyak, maka selaksa dalam Shamadiyah sesuai, berbeda dengan selaksa jika yang dimaksud adalah jumlah yang pasti, maka selaksa dalam Shamadiyah kurang sesuai karena selaksa yang menunjukkan jumlah berbeda jauh pada kenyataan yang ada dilapangan yaitu selaksa arti sebenarnya 10.000 sedangkan dalam Shamadiyah 100.000.

Data yang diperoleh di lapangan tentang prosesi Shamadiyah diawali dengan berkumpulnya dahulu orang yang akan mengikuti Shamadiyah, kemudian membaca alFatihah, tawasul pada Nabi, Abdul Qadir Jaelani, ulama atau guru, sesepuh yang lebih dulu meninggal, lalu Shamadiyah yang dikhususkan membaca surah al-Ikhlash, terakhir ditutup doa. Terkadang ada pembacaan Surah Yasin dan Tahlil sebelum doa yang bergantung kepada pemimpin atau pelaksana Shamadiyah.

Sedangkan observasi yang peneliti lakukan dengan berperan aktif dalam prosesi Shamadiyah, Shamadiyah diawali dengan berkumpul terlebih dahulu. Sebelum Shamadiyah dimulai, tuan rumah menyiapkan segala hal yang diperlukan dalam prosesi pelaksanaan Shamadiyah. Umumnya ibu-ibu lebih menyibukkan di dapur unuk menyiapkan suguhan yang akan diberikan kepada yang menghadiri Shamadiyah, sedangkan untuk bapak-bapak menyiapkan dan menata tempat. Observasi yang dilakukan di kediaman Efendi, peneliti menemukan beberapa orang bahkan lebih yang sedang membaca surah al-Ikhlash menggunakan tasbih. Sehingga sebelum dimulai orang yang lebih dulu membaca surah al-Ikhlash tersebut menyampaikan jumlah yang sudah dibacanya kepada yang bertugas mencatat surah al-Ikhlash yang sudah dibaca. Dalam observasinya, peneliti diberitahu bahwa jumlah ini tidak hanya berpatokan pada orang yang membaca disini (di kediaman yang punya hajatan), kadang keluarga yang jauh juga

\footnotetext{
${ }^{44}$ https://www.taufiq.net/2012/07/fidaan.html diakses pada 1 Oktober 2019

${ }^{45} \mathrm{https}: / /$ www.serbatahu.com/arti/gaul/selaksa diakses pada 1 Oktober 2019

${ }^{46} \mathrm{http} / / /$ www.sarapanpagi.org/selaksa-revavah-studi-kata-ibrani-vt3344.html diakses pada 1 Oktober 2019
} 
ikut berpartisipasi dengan memberitahukan jumlah surah al-Ikhlash yang dibacanya. Sehingga partisipan dalam Shamadiyah tidak diharuskan berada di lokasi prosesi Shamadiyah. ${ }^{47}$

Sebelum Shamadiyah dimulai, peneliti menanyakan bagaimana cara menghitungnya. Salah satu partisipan menjelaskan bahwa cara menghitungnya setiap satu biji tasbih atau kerikil sama dengan sepuluh Surah al-Ikhlash. Shamadiyah dimulai ketika sudah berkumpul semua yang akan berpartisipasi. Shamadiyah dipimpin oleh orang yang dipercaya seperti tokoh masyarakat atau yang lebih sepuh. Pemimpin Shamadiyah bergantung pada kondisi, bisa saja berubah sesuai berkumpulnya semua partisipan. Bisa dilaksanakan selama beberapa jam atau kurang dan bisa lebih. Pemimpin mengawali prosesi Shamadiyah dengan tawasul dan surah al-Fatihah yang dikhususkan pada Rasulullah, Abdul Qadir Jaelani, Guru, sesepuh yang lebih dulu meninggal dengan bersama-sama, kemudian dilanjutkan dengan Shamadiyah. Dalam pembacaan Surah alIkhlash, partisipan yang berpartisipasi membacanya secara individu tanpa dipandu atau dipimpin lagi oleh pemimpin Shamadiyah ketika memulai membaca Surah al-Ikhlash. Setelah pemimpin menyatakan selesai untuk pembacaan Surah al-Ikhlash, pemimpin mengakhirinya dengan doa yang dikhususkan kepada yang meninggal. Setelah membaca doa, yang bertugas mencatat jumlah Surah al-Ikhlash menanyakan satu persatu partisipan tentang jumlah tasbih atau kerikil yang sudah terpakai, kemudian menjumlahkannya semua yang sudah dibaca. Setelah selesai dicatat, maka semua partisipan dipersilahkan untuk menikmati hidangan yang sudah disiapkan. ${ }^{48}$

Peneliti tidak menemukan kajian ilmiah atau teori yang menjelaskan secara mendalam bagaimana urutan prosesi Shamadiyah. Sehingga penjelasan tentang urutan prosesi Shamadiyah di kampung Krepek termasuk kedalam penemuan baru.

Berdasarkan data yang didapatkan di lapangan alat-alat yang digunakan dalam prosesi Shamadiyah yaitu alat tulis berupa kertas atau buku dan pulpen, alat hitung dapat berupa tasbih, kerikil, atau biji-bijian. Biji yang digunakan dapat berupa biji asam (maghi) atau biji sagha. Untuk cara mengitungnya adalah setiap 1 biji tasbih atau kerikil sama dengan 10 surah al-Ikhlash dan dicatat jumlah tiap biji yang sudah digunakan. Hal ini sesuai dengan observasi yang dilakukan dalam partisipasi prosesi Shamadiyah bahwa alat dan cara menghitung yang digunakan seperti itu.

Bagi masyarakat kampung Krepek, pembacaan surah al-Ikhlash dalam tradisi Shamadiyah memiliki makna dan keutamaan tersendiri. Ketika mereka membaca surah al-Ikhlash dalam Shamadiyah, mereka mengharap barokah dari surah al-Ikhlash. Disisi lain Shamadiyah yang ditujukan kepada orang yang meninggal, makna surah al-Ikhlash diyakini bisa menebus dosa orang yang meninggal dari yang paling ringan hingga berat. Keutamaan seperti ini mereka sebut dengan fidaan min al-nar (tebusan dari siksa api neraka), maksudnya adalah menghindarkan orang yang meninggal dari siksa api neraka atau siksa kubur.

${ }^{47}$ Efendi Harun, Tokoh masyarakat, observasi (3 Agustus 2019)

${ }^{48}$ Ibid., 
Keyakinan mereka senada dengan salah satu keutamaan surah al-Ikhlash yang diambil dari sabda Rasulullas Saw., "Barang siapa yang membaca surah al-Ikhlash di atas kuburan sebanyak 11 kali, kemudian menghadiahkan pahalanya kepada penghuni kubur, penghuni kubur tersebut akan diberi pahala sebanyak orang yang sudah mati." 49

Selain itu juga terdapat berbagai macam keutamaan yang terkandung dalam surah al-Ikhlash sebagai berikut: ${ }^{50}$

Pertama, bila dibacakan pada orang yang sedang sakit kemudian mati hari itu juga, maka insyaAllah dia akan diselamakan dari siksa kubur.

Kedua, bila dibaca secara rutin selesai salat fardhu, maka insyaAllah akan mendapatkan kebaikan dunia akhirat.

Ketiga, bila dalam perjalanan kemudian merasa lapar atau dahaga padahal tidak didapati tempat makan (warung), kemudian membaca ya shamad sebanyak-banyaknya, insyaAllah tidak merasakan lapar atau dahaga kembali.

Keempat, bila diamalkan sebagai wirid lafal ya shamad secara rutin sebanyak 134 kali, insyaAllah diselamatkan dari orang jahat.

Kelima, bila lafal ya shamad diwiridkan empat puluh kali secara rutin, maka Allah akan selamat dari tipu daya orang jahat.

Data yang diperoleh di lapangan, menunjukkan terdapat beberapa keyakinan atau motivasi masyarakat yang menjadi semangat untuk melestarikan pembacaan surah al-Ikhlash dalam tradisi Shamadiyah sebagai berikut;

Pertama, mengharap barokah dari Surah al-Ikhlash ditujukan kepada yang meninggal.

Kedua, penebus dosa orang yang meninggal dan dibebaskan dari api neraka.

Ketiga, mengharap barokah dan sebagai penebus dosa orang yang meninggal.

Keempat, sebagai fidaan min al-nar (tebusan dari siksa api neraka) yang dikhususkan kepada almarhum atau almarhumah dalam kubur

Kelima, diampuni dosanya

Keenam, diterima amal ibadahnya

Ketujuh, dimasukan ke dalam surga Allah, insyaAllah

Kedelapan, QS. Ghafir : 60

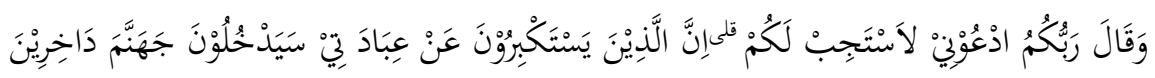

Dan Tuhanmu berfirman: "Berdoalah kepada-Ku, niscaya akan Kuperkenankan bagimu. Sesungguhnya orang-orang yang menyombongkan diri dari menyembah-Ku akan masuk neraka Jahannam dalam keadaan hina dina" (QS. Ghafir : 60) ${ }^{51}$

Kesembilan, QS.al-Hasr : 10

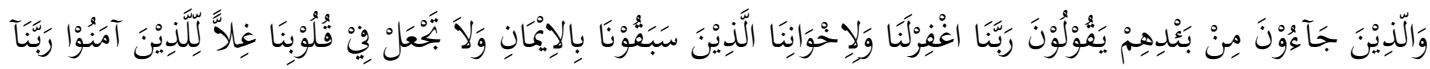

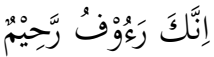

49 Syekh Ahmad Dairobi al-Kabir, Kitab Mujarrobat : Referensi Terlengkap Ilmu Pengobatan dan Penyembuhan Islam (Jakarta Selatan: WaliPustaka, 2018), 112

${ }^{50}$ Labib MZ, Primbon Mujarobat Kubro (Surabaya: Pustaka Agung Harapan, 2013), 244

${ }^{51}$ Departemen Agama Republik Indonesia, Al-Qur'an dan Terjemahannya, 767 
Dan orang-orang yang datang sesudah mereka (Muhajirin dan Anshor), mereka berdoa: "Ya Rabb kami, beri ampunlah kami dan saudara-saudara kami yang telah beriman lebih dulu dari kami, dan janganlah Engkau membiarkan kedengkian dalam hati kami terhadap orang-orang yang beriman; Ya Rabb kami, Sesungguhnya Engkau Maha Penyantun lagi Maha Penyayang" (QS.al-Hasr : 10) $)^{52}$

Dalam penafsiran Quraish Shihab surah al-Ghafir ayat 60, ayat ini menunjukkan bahwa Allah Swt. sangat menyukai hamba-hamba yang memohon pada-Nya dalam bentuk doa yang dianjurkan setiap saat. Sebaliknya, hamba yang tercela adalah hamba yang seperti kaum Musryikin yang berdoa hanya saat tertentu atau dalam kesulitan. Hal ini tidak hanya mencerminkan kerendahan moral dan tidak menyadari bahwa setiap saat seorang hamba membutuhkan Allah Swt. ${ }^{53}$

Sebuah hadis memperkuat pendapat ini bahwa berdoa merupakan perilaku nabi Saw. yang mendoakan orang-orang yang sudah meninggal dan dimakamkan di Baqi' dan berdoa, "Ya Allah, berilah ampunan bagi ahli Baqi' al-Gharqad". Hadis tersebut menggambarkan bagaimana Rasulullah bersikap terhadap orang yang meninggal, yaitu dengan mendoakannya. Hadis yang menggambarkannya sebagai berikut: 54

"Aisyah memberikan kesaksiannya, bahwa terkadang Rasulullah Saw. berkunjung untuk ziarah ke makam Baqi' di dekat Masjid al-Nabawi Madinah pada malam hari. Setelah Nabi Saw. memanjatkan dan mengucapkan salam yang ditujukan pada mereka yang sudah meninggal dan dimakamkan di Baqi', maka Rasulullah Saw. juga menekankan bahwa kelak, Rasulullah juga akan mendatangi mereka pada saat penentuan janji Allah di hari kiamat, dan Rasulullah menyatakan bahwa beliau juga akan menyusul mereka (meninggal dunia). Kemudian Rasulullah berdoa, mendoakan semua arwah yang dimakamnkan di pemakaman Baqi' tersebut."

Berdoa untuk kaum muslimim baik yang hidup dan mati adalah anjuran agama dan disisi lain membaca Al-Qur'an juga bernilai ibadah. Rasulullah Saw. memerintahkan untuk besedekah yang ditujukan untuk orang yang meninggal walaupun dengan seteguk air, jika tidak mampu maka bersedekah dengan bacaan ayat Al-Qur'an, jika tidak mengerti Al-Qur'an, maka berdoa untuk memintakan ampunan dan rahmat Allah Swt. Menurut Syaikh al-Husaini, segenap pahala bacaan Al-Qur'an dan ibadah seseorang dapat sampai pada orang yang meninggal, mereka dapat menerimanya dengan ampunan atas dosa, terangkat derajatnya, kesenangan dan pahala lain yang dikehendaki Allah Swt. wallahu a'lam. ${ }^{55}$

Sesuai dengan data yang diperoleh dilapangan, bahwa tujuan utama yang dilakukan Shamadiyah adalah berkirim doa dan pahala dari ibadah yang dilakukan

\footnotetext{
52 Ibid., 917

${ }^{53}$ M. Quraish Shihab, Tafsir al-Misbah: Pesan,Kesan dan Keserasian al-Qur'an, 649

54 Muhammad Solikhin, Ritual Kematian Islam Jawa: PengaruhTradisi Lokal Indonesia Dalam Ritual Kematian Jawa, 153

${ }^{55}$ Ibid., 176
} 
orang lain, baik keluarga atau siapapun yang ditujukan untuk orang yang meninggal akan sampai pada ahli kubur. Namun manusia tidak mengetahui apakah akan benarbenar sampai atau tidak, semua bergantung pada kehendak Allah Swt. Hal ini sesuai dengan ayat dan hadis yang mereka jadikan pedoman, karena pada dasarnya Shamadiyah dilakukan untuk mendoakan dan mengirimkan pahala ibadah dengan membaca ayat Al-Qur'an pada ahli kubur, serta memohonkan ampun atas siksa dan dosanya.

\section{PENUTUP}

Shamadiyah merupakan forum yang dilakukan saat ada orang yang meninggal yang membaca Qulhu atau Surah al-Ikhlash sebanyak 100.000 kali. Shamadiyah dilestarikan karena ada cerita pelaksanaan Shamadiyah oleh ulama. Shamadiyah bisa diikuti siapa saja bahkan orang jauh sekalipun melalui media untuk memberitahukan jumlah surah al-Ikhlash yang dibaca. Shamadiyah biasanya dilaksanakan selepas hari ke tujuh hingga hari ke empat puluh kematian. Alat yang digunakan berupa alat tulis dan alat hitung (tasbih, kerikil, atau biji-bijian (biji asam (maghi) atau biji sagha)). Setiap 1 biji tasbih atau kerikil sama dengan 10 Surah al-Ikhlash dan dicatat jumlah tiap biji yang sudah digunakan. Pembacaan Surah ak-Ikhlash dalam Shamadiyah mengharap barokah dari Surah al-Ikhlash dan diyakini bisa menebus dosa orang yang meninggal atau fidaan min al-nar (tebusan dari siksa api neraka). Motif atau motivasi yang menjadi semangat mereka membaca Surah al-Ikhlash berdasarkan ayat dan hadis.

\section{DAFTAR PUSTAKA}

Ajami, Nuha. 'Metodologi Penelitian The Living qur'an dan Hadits'. Kota Metro: Institur Agama Negeri Metro. t.th.

Al-Kabir, Syekh Ahmad Dairobi. Kitab Mujarrobat : Referensi Terlengkap Ilmu Pengobatan dan Penyembuhan Islam. Jakarta Selatan: Wali Pustaka. 2018.

Ammar, Wafi Marzuqi. Tafsir Tematik al-Wafi : Menyelami Kandungan Ayat Sesuai Tema dari Surah-surah dalam Al-Qur'an. Gresik: Waraqah Mitra Media. 2013.

Departemen Agama Republik Indonesia. Al-Qur'an dan Terjemahnya. Surabaya: alHidayah. 2019.

Departemen Pendidikan Dan Kebudayaan. Upacara Tradisional (Upacara Kematian) Daerah Istimewa Aceh. Jakarta: Departemen Pendidikan dan Kebudayaan Proyek Inventarisasi dan Dokumentasi Kebudayaan Daerah. 1984.

Intan Ervina. "Ritual Peutron Aneuk dan Dampaknya Terhadap Kehidupan Masyarakat di Gampong Tokoh Kecamatan Manggeng Kabupaten Aceh Barat Daya". Skripsi S.KI. Universitas Islam Negeri Ar-Raniry. Aceh. 2017.

Kamus Besar Bahasa Indonesia. Edisi Keempat. Jakarta: Gramedia Purtaka. 2013.

Maslita. "Kenduri Jirat di Gampong Ruak Kecamatan Kluet Utara Kabupaten Aceh Selatan (Ritual, Ajaran, Nilai). t.th. 
MZ, Labib. Primbon Mujarobat Kubro. Surabaya. Pustaka Agung Harapan. 2013.

Raco, J.R. Metode Penelitian Kualitatif Jenis, Karakteristik, dan Keunggulannya. Jakarta: Grasindo. 2010.

Shihab, M. Quraish. Tafsir al-Misbah: Pesan, Kesan dan Keserasian al-Qur'an. Jakarta: Letera Hati. 2002.

Solikhin, Muhammad. Ritual Kematian Islam Jawa: PengaruhTradisi Lokal Indonesia Dalam Ritual Kematian Jawa. Yogyakarta: Narasi. 2010.

Surin, Bachtiar. adz-Dzikraa. Bandung: Angkasa Bandung. 1991.

http://www.nu.or.id/post/read/39568/Samadiyah-wujud-kesalehan-anak diakses pada 1 April 2019

https://www.taufiq.net/2012/07/fidaan.html diakses pada 1 Oktober 2019

https://www.serbatahu.com/arti/gaul/selaksa diakses pada 1 Oktober 2019

http://www.sarapanpagi.org/selaksa-revavah-studi-kata-ibrani-vt3344.html diakses pada 1 Oktober 2019 